Maruta N. ${ }^{1}$, Yaroslavtsev S. ${ }^{2}$, Oprya Ye. ${ }^{3}$, Kalenskaya G. ${ }^{1}$, Kutikov O. ${ }^{1}$

${ }^{1}$ Institute of Neurology, Psychiatry and Narcology of the NAMS of Ukraine, Kharkiv, Ukraine

${ }^{2}$ Kherson Regional Institution for Psychiatric Care Delivery, Kherson region, Ukraine

${ }^{3}$ Odessa National Medical University, Odessa, Ukraine

Марута Н.А. ${ }^{1}$, Ярославцев С.А. ${ }^{2}$, Опря Е.В. ${ }^{3}$, Каленская Г.Ю. ${ }^{1}$, Кутиков А.Е. ${ }^{1}$

${ }^{1}$ Институт неврологии, психиатрии и наркологии Национальной академии медицинских наук Украины, Харьков, Украина

${ }^{2}$ Херсонское областное заведение по оказанию психиатрической помощи, Херсонская область, Украина

${ }^{3}$ Одесский национальный медицинский университет, Одесса, Украина

\title{
Structure of Cognitive Impairments in Depressive Disorders and Principles of their Therapy
}

\author{
Структура когнитивных нарушений при депрессивных \\ расстройствах и принципы их терапии
}

\begin{abstract}
In the study, 362 patients with cognitive impairments in depressive disorders were examined: 123 patients with recurrent depressive disorder (RDD), 141 patients with bipolar affective disorder (BAD), and 98 people with prolonged depressive reaction (PDR). It was found that cognitive dysfunctions were less pronounced in patients with PDR if compared to patients with RDD and $\operatorname{BAD}(p<0,035)$. Cognitive dysfunctions in depressive disorders were underlined by the presence of impairments in the mental sphere, in the sphere of attention, in executive, visual-spatial, and linguistic functions. Differential peculiarities of cognitive impairments in RDD, BAD and PDR were revealed. These peculiarities should be taken into account during performing differential diagnostics of cognitive impairments in depressive disorders.

A comprehensive program of therapy and rehabilitation for patients with cognitive impairment in depressive disorders was worked out. This program was implemented in four stages: diagnostic, therapeutic, rehabilitation and prevention. The diagnostic stage included a clinical and psychopathological assessment of patients' cognitive disorders, analysis of their anamnestic data, clinical symptoms, dynamics and prognosis of the disease, relationship between clinical and socio-psychological factors. The therapeutic stage included a complex of pharmacotherapeutic and psychotherapeutic measures to correct cognitive impairments, to stop depressive symptoms, to normalize psychoemotional conditions, a patient's social adjustment and readjustment. The rehabilitation stage included a set of pharmacotherapeutic and psychotherapeutic measures aimed at restoring cognitive functions, consolidating the effect of antidepressant therapy, and restoring a patient's social functioning. The prevention stage was designed to maintain normal psychoemotional conditions, to resist stress effectively, and to prevent the recurrence of the depressive disorder. The effectiveness of the proposed program was proved. Its effect consists in a more significant reduction of clinical manifestations of depressive disorders, improvement of cognitive functions, reduction of maladaptive and increase of adaptive strategies of cognitive regulation of emotions, improvement of social functioning in the main life spheres.
\end{abstract}

Keywords: patients with cognitive impairments, depressive disorders, cognitive dysfunctions, recurrent depressive disorder, bipolar depressive disorder, prolonged depressive reaction, therapy and rehabilitation, social functioning. 
Было обследовано 362 пациента с когнитивными нарушениями при депрессивных расстройствах: 123 пациента с рекуррентными депрессивными расстройствами (РДР), 141 пациент с биполярными аффективными расстройствами (БАР) и 98 человек с пролонгированной депрессивной реакцией (ПДР). Было установлено, что при ПДР когнитивная дисфункция была менее выраженной, чем при РДР и БАР $(p<0,035)$. Когнитивная дисфункция при депрессивных расстройствах очерчивалась наличием нарушений в умственной сфере, в сфере внимания, исполнительных, зрительно-пространственных и языковых функциях. Выделены дифференциальные особенности когнитивных нарушений при РДР, БАР и ПДР, которые следует учитывать при проведении дифференциальной диагностики когнитивных нарушений при депрессивных расстройствах.

Разработана комплексная программа терапии и реабилитации пациентов с когнитивными нарушениями при депрессивных расстройствах, которая реализовывалась в четыре этапа: диагностический, терапевтический, реабилитационный и профилактический. Диагностический этап включал клинико-психопатологическую оценку имеющихся у пациентов расстройств когнитивной сферы, анализ анамнестических данных, клинической симптоматики, динамики и прогноза заболевания, взаимосвязи клинических и социально-психологических факторов. Терапевтический этап включал комплекс мероприятий фармакотерапии и психотерапии, направленных на коррекцию когнитивных дисфункций, купирование депрессивной симптоматики, нормализацию психоэмоционального состояния, социальной адаптации и реадаптацию пациента. Реабилитационный этап включал комплекс мероприятий фармакотерапии и психотерапии, направленных на восстановление когнитивных функций, укрепление эффекта от антидепрессивной терапии, восстановление социального функционирования пациента. Профилактический этап предназначен для поддержания нормального психоэмоционального состояния, эффективного сопротивления стрессам, предотвращения рецидивов ДР. Доказана эффективность предложенной программы, заключающаяся в более выраженной редукции клинических проявлений депрессивных расстройств, улучшении когнитивных функций, снижении неадаптивных и повышении адаптивных стратегий когнитивного регулирования эмоций, улучшении социального функционирования в основных сферах жизнедеятельности.

Ключевые слова: пациенты с когнитивными нарушениями, депрессивные расстройства, когнитивная дисфункция, рекуррентное депрессивное расстройство, биполярное депрессивное расстройство, пролонгированная депрессивная реакция, терапия и реабилитация, социальное функционирование.

\section{- INTRODUCTION}

The urgency of the problem discussed is determined by a high prevalence of depressive disorders (DDs) in the general population, their tendency towards a protracted and chronic course, and a high suicidal risk. According to modern data, the prevalence of this pathology in the population is at least 5.5-11.3\% [1-3]. In recent decades, the problem of cognitive impairments (Cls) in DDs in a general clinical practice is increasingly important and has been becoming one of priorities for a medical science and the health care system $[2,4,5]$. The relevance of studying $\mathrm{Cls}$ in DDs is due to a low quality of diagnoses, a negative impact on the development, course and prognosis of many somatic diseases, on patients' working capacities and quality of life, as well as to a high socio-economic burden of depressions [1, 4-7]. A powerful 
progress of the era of psychopharmacology, nevertheless, did not solve the problem of care for patients with $\mathrm{Cls}$ and affective disorders. To date, there is no unified standardized therapy for cognitive dysfunction in DDs. An insufficient attention is still paid to the diagnosis of cognitive decline in DDs: neuropsychological examinations are not always applied; diagnostic tests are not sensitive to mild cognitive impairments; the presence of $\mathrm{Cls}$ without elements of a non-adjusting behavior is not taken into account; the factors underlying dysfunctions have been poorly studied, and there are no comprehensive programs that can influence patients' cognitive functions and depressive conditions $[1,3,5,7,12]$. All of the mentioned above defined the aim of our research.

\section{- AIM OF THE STUDY}

Is to investigate the structure of cognitive impairments in various types of depressive disorders and to develop principles of their therapy.

\section{- OBJECT AND RESEARCH METHODS}

The study involved 362 patients with DDs. We examined 123 patients with recurrent depressive disorder (RDD), 141 patients with bipolar affective disorder (BAD), and 98 patients with prolonged depressive reaction (PDR). There were 57 men $(46.34 \pm 2.78) \%$ and 66 women $(53.66 \pm 2.99) \%$ among the examined patients with $\mathrm{Cls}$ in RDD, 76 men $(53.90 \pm 2.61) \%$ and 65 women $(46.10 \pm 2.42) \%$ among patients with BAD, and 43 men $(43.88 \pm 3.39) \%$ and 55 women $(56.12 \pm 3.83) \%$ among patients with PDR, that corresponds in general to the typical sex distribution in DDs. Thus, female patients predominated among the examined persons $(51.96 \%$, diagnostic coefficient $(D C)=0.66$, measure of informativeness $(\mathrm{MI})=0.02, \mathrm{p}=0.046)$, whereas male patients prevailed in the group with $\mathrm{BAD}(53.90 \%, \mathrm{DC}=0.66, \mathrm{Ml}=0.02$, $\mathrm{p}=0.046)$. The vast majority of patients with $\mathrm{Cls}$ in DDs were of the age from 30 to 44 years old (38.12\%). There were more young people (18-29 years old) among patients with PDR $(21.43 \%, \mathrm{DC}=8.19, \mathrm{Ml}=0.74, \mathrm{p}=0.0001)$ and among patients with $\operatorname{BAD}(31.21 \%, \mathrm{DC}=9.82, \mathrm{Ml}=1.37, \mathrm{p}=0.0001)$, and there were more middle-aged (45-59 years old) and elderly people (60-65 years old) among patients with $\mathrm{RDD}(37.40 \% \mathrm{DC}=1.54, \mathrm{Ml}=0.09, \mathrm{p}=0.016$ and $17.07 \%$, $\mathrm{DC}=4.78, \mathrm{Ml}=0.27, \mathrm{p}=0.002$, respectively).

To study clinical-psychopathological peculiarities of Cls in DDs, a set of research methods was used: clinical-psychopathological, psychodiagnostic (Montreal Cognitive Assessment Scale (MoCA), Modified Addenbrook Cognitive Scale (ACE-R), "Ten Words Memorizing", Dot Cancellation Test, Trial Making Test (TMT), Verbal Fluency Test (VFT)), the Scale of Personal and Social Functioning (PSP), and statistical ones (Student's t-test and Fisher's exact test with determination of the measure of informativeness (MI) and diagnostic coefficients (DC)) [13-19].

\section{- RESULTS AND DISCUSSION}

The investigation of the peculiarities of $\mathrm{Cls}$ in DDs included an analysis of the level of expression of cognitive dysfunctions, peculiarities of cognitive processes and executive functions in patients with DDs. The analysis of the clinical-psychopathological peculiarities of cognitive disorders in 
Table 1

Impairments of cognitive functions in patients with depressive disorders

Таблица 1

Нарушения когнитивных функций у пациентов с депрессивными расстройствами

\begin{tabular}{|l|l|l|l|l|l|l|}
\hline \multirow{2}{*}{ Cognitive impairments } & \multicolumn{2}{l}{ RDD $(\mathbf{n}=\mathbf{1 2 3})$} & \multicolumn{2}{l|}{ BAD $(\mathbf{n = 1 4 1 )}$} & \multicolumn{2}{l|}{ PDR (n=98) } \\
\cline { 2 - 8 } & $\mathbf{n}$ & $\mathbf{\%} \mathbf{m}$ & $\mathbf{n}$ & $\mathbf{\%} \pm \mathbf{m}$ & $\mathbf{n}$ & $\mathbf{\%} \pm \mathbf{m}$ \\
\hline Ideas of inferiority & 74 & $60.16 \pm 3.11$ & 97 & $68.79 \pm 2.74$ & 74 & $75.51 \pm 3.85$ \\
\hline Hypochondriacal ideas & 67 & $54.47 \pm 3.01$ & 54 & $38.30 \pm 2.15$ & 61 & $62.24 \pm 3.94$ \\
\hline Suicidal thoughts & 72 & $58.54 \pm 3.09$ & 86 & $60.99 \pm 2.72$ & 72 & $73.47 \pm 3.90$ \\
\hline Rigidity of thinking & 98 & $79.67 \pm 2.94$ & 92 & $65.25 \pm 2.75$ & 43 & $43.88 \pm 3.39$ \\
\hline Decreased level of interests & 122 & $99.19 \pm 0.73$ & 107 & $75.89 \pm 2.66$ & 58 & $59.18 \pm 3.90$ \\
\hline Difficulties with decision making & 111 & $90.24 \pm 2.31$ & 99 & $70.21 \pm 2.74$ & 61 & $62.24 \pm 3.94$ \\
\hline Obsessive thoughts & 97 & $78.86 \pm 2.97$ & 87 & $61.70 \pm 2.73$ & 84 & $85.71 \pm 3.34$ \\
\hline Hypersensitivity to criticism & 76 & $61.79 \pm 3.13$ & 104 & $73.76 \pm 2.70$ & 81 & $82.65 \pm 3.55$ \\
\hline Paranoid disorders & 4 & $3.25 \pm 0.26$ & 18 & $12.77 \pm 0.85$ & 0 & 0.00 \\
\hline Memory impairments & 63 & $51.22 \pm 2.93$ & 71 & $50.35 \pm 2.53$ & 37 & $37.76 \pm 3.07$ \\
\hline Reduced concentration & 101 & $82.11 \pm 2.85$ & 132 & $93.62 \pm 1.69$ & 87 & $88.78 \pm 3.07$ \\
\hline Rapid depletion of mental activity & 78 & $63.41 \pm 3.14$ & 127 & $90.07 \pm 2.03$ & 56 & $57.14 \pm 3.86$ \\
\hline
\end{tabular}

patients with DDs allowed us to determine, that patients with RDD had a decreased level of interests $(99.19 \pm 0.73) \%$, difficulties with decision making $(90.24 \pm 2.31) \%$, a reduced concentration $(82.11 \pm 2.85) \%$, rigidity of thinking (79.67 \pm 2.94$) \%$, and obsessive thoughts $(78.86 \pm 2.97) \%$ (Table 1).

Problems with concentration $(93.62 \pm 1.69) \%$, depletion of mental activity $(90.07 \pm 2.03) \%$, apathy $(75.89 \pm 2.66) \%$, an increased sensitivity to criticism (73.76 \pm 2.70$) \%$, difficulties with decision making $(70.21 \pm 2.74) \%$, and ideas of inferiority $(68.79 \pm 2.74) \%$ were the most frequent in patients with BAD. Patients with RDD had decreased levels of concentration $(88.78 \pm 3.07) \%$, the presence of obsessive and suicidal thoughts $(85.71 \pm 3.34 \%$ and $73.47 \pm 3.90 \%$, respectively), hypochondriacal ideas and ideas of inferiority $(62.24 \pm 3.94 \%$ and $75.51 \pm 3.85 \%$, respectively), an increased sensitivity to criticism $(82.65 \pm 3.55) \%$, and difficulties with decision making $(62.24 \pm 3.94) \%$.

The statistical analysis of the results allowed us to define, that rigidity of thinking, apathy and difficulties with decision making were manifested more often in patients with RDD in comparison with patients with BAD $(\mathrm{DC}=0.87, \mathrm{Ml}=0.06, \mathrm{p}<0.003 ; \mathrm{DC}=1.16, \mathrm{Ml}=0.14, \mathrm{p}<0.0001$ and $\mathrm{DC}=1.09$, $\mathrm{Ml}=0.11, \mathrm{p}<0.0001$, respectively) and $\mathrm{PDR}(\mathrm{DC}=2.59, \mathrm{Ml}=0.46, \mathrm{p}<0.0001$; $D C=2.24, \mathrm{Ml}=0.45, \mathrm{p}<0.0001$; and $\mathrm{DC}=1.61, \mathrm{Ml}=0.23, \mathrm{p}<0.0001$, respectively), who had more ideas of inferiority $(D C=0.58, M l=0.03, p<0.035$ and $D C=0.99$, $\mathrm{Ml}=0.08, \mathrm{p}<0.006$, respectively). Patients with $\mathrm{BAD}$ had a higher frequency of paranoid disorders as compared with patients with $\mathrm{RDD}(\mathrm{DC}=5.94, \mathrm{Ml}=0.28$, $p<0.003)$ and PDR $(p<0.0001)$, who had more hypochondriacal ideas $(\mathrm{DC}=1.53, \mathrm{Ml}=0.12, \mathrm{p}<0.003$ and $\mathrm{DC}=2.11, \mathrm{Ml}=0.25, \mathrm{p}<0.0001$, respectively) and obsessive thoughts $(\mathrm{DC}=1.07, \mathrm{Ml}=0.09, \mathrm{p}<0.001$ and $\mathrm{DC}=1,43, \mathrm{Ml}=0.17$, $p<0.0001$, respectively). It was also demonstrated, that patients with $B A D$ were more likely to have problems with concentration, a rapid depletion of mental processes as compared with patients with $\mathrm{RDD}(\mathrm{DC}=0.57, \mathrm{Ml}=0.03$, $\mathrm{p}<0.0023$ and $\mathrm{DC}=1.52, \mathrm{Ml}=0.20, \mathrm{p}<0.0001$, respectively). Patients with PDR were more likely to have suicidal thoughts and sensitivity to criticism as 
compared with patients with $\mathrm{RDD}(\mathrm{DC}=0.99, \mathrm{Ml}=0.07, \mathrm{p}<0.007$ and $\mathrm{DC}=1.26$, $\mathrm{Ml}=0.13, \mathrm{p}<0,0003$, respectively) and $\mathrm{BAD}(\mathrm{DC}=0.81, \mathrm{Ml}=0.05, \mathrm{p}<0.014$ and $\mathrm{DC}=0.49, \mathrm{Ml}=0.02, \mathrm{p}<0.034$, respectively), who had more memory impairments $(D C=1.32, \mathrm{Ml}=0.09, \mathrm{p}<0.035$ and $\mathrm{DC}=1.25, \mathrm{Ml}=0.08, \mathrm{p}<0.016$, respectively).

The psychodiagnostic investigation of impairment of cognitive processes with the MoCA scale demonstrated, that patients with DD were characterized with decreased cognitive functions: the average total scores were $25.71 \pm 5.54$ points for patients with RDD, $25.32 \pm 4.87$ points for patients with $B A D$, and $26.23 \pm 3.12$ points for patients with $P D R$ ( $N \geq 26$ points). The statistical analysis of the results showed that patients with $B A D$ had more pronounced cognitive dysfunctions than patients with PDR $(p<0.035)$. There were no significant differences in terms of cognitive dysfunction levels between patients with RDD and patients with BAD and PDR.

Results of application of the Addenbrook Cognitive Scale (ACE-R) enabled an assessment of cognitive functions such as memory, attention, speech, speech activity and visual-spatial functions in patients with DDs (Figure).

It was found out, that the verbal fluency $(10.13 \pm 0.15$ points), impaired visual-spatial functions $(13.72 \pm 0.42$ points), and impaired attention (16.37 \pm 0.81 points) were most pronounced impairments of cognitive functions in patients with RDD. For patients with BAD, a similar tendency was observed: low scores were obtained on the "verbal fluency" scale $(9.07 \pm 0.12$ points), difficulties of concentration ( $14.45 \pm 0.38$ points) and impaired visualspatial functions (14.15 \pm 0.32 points). Patients with PDR had a decreased verbal fluency (12.68 \pm 0.43 points), impaired visual-spatial functions, and concentration ( $15.76 \pm 0.58$ and $17.38 \pm 0.87$ points, respectively).

The results of the mathematical processing of the data obtained showed that patients with BAD had more manifested impairments in orientation / attention, verbal fluency and speech processes than patients with RDD $(p<0.025, p<0.043$, and $p<0.038$, respectively) and PDR $(p<0.001, p<0.0001$,

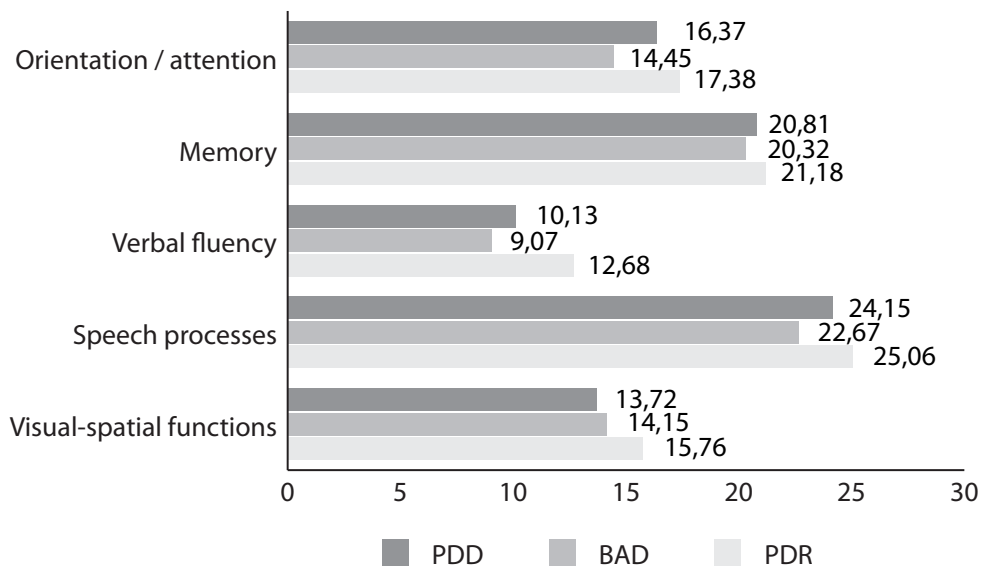

\section{Peculiarities of cognitive functions in patients with DDs (according to ACE-R results)}

Особенности когнитивных функций у пациентов с депрессивными расстройствами (по результатам ACE-R) 
and $p<0.0006$, respectively). It should be noted, that in terms of orientation / attention and verbal fluency, patients with RDD had more pronounced disorders than patients with PDR ( $p<0.034$ and $p<0.01$, respectively). Visualspatial functions were more impaired in patients with RDD and BAD than in patients with PDR $(p<0.01$ and $p<0.025$, respectively).

The investigation of mnestic processes showed that the level of shortterm memory was reduced and amounted to $4.32 \pm 2.19$ words (with $\mathrm{N}=7 \pm 2$ ) in patients with RDD. In patients with $B A D$, the level of short-term memory was also below normal and amounted to $4.52 \pm 2.78$ words; patients with PDR had their levels of short-term memory in the lower limits of the norm $5.37 \pm 1.06$ words. A comparison of the results showed differences between the groups, consisting in a lower level of short-term memory in patients with RDD and BAD as compared with patients with PDR $(p<0.025$ and $p<0.048$, respectively). It was also determined, that the level of mnestic processes was higher in patients with PDR than in patients with BAD $(p<0.027)$. A medium level of a delayed reproduction was registered in the majority of patients with RDD $(50.41 \pm 2.91) \%$ and BAD $(49.65 \pm 2.52) \%$, whereas a high level of a delayed reproduction was fixed in PDR (58.16 \pm 3.88$) \%$ (Table 2).

It was found out, that there were more persons with a high level of a delayed reproduction among patients with PDR as compared with patients with RDD ( $\mathrm{DC}=1.82, \mathrm{Ml}=0.18, \mathrm{p}<0.001)$ and $\mathrm{BAD}(\mathrm{DC}=3.58, \mathrm{Ml}=0.58$, $p<0.0001$ ), along with this, there were more persons with a high level of a delayed reproduction among patients with RDD than among patients with $B A D(D C=1.75, M l=0.11, p<0.009)$. It was also demonstrated, that there were more persons with a medium level of a delayed reproduction among patients with RDD and BAD, as compared with patients with PDR (DC=2.47, $\mathrm{Ml}=0.27, \mathrm{p}<0.0004$ and $\mathrm{DC}=2.40, \mathrm{Ml}=0.25, \mathrm{p}<0.0005)$. Among patients with BAD there was a large number of persons with a reduced level of a delayed reproduction as compared with patients with $\mathrm{RDD}$ and PDR $(D C=3.53$, $\mathrm{Ml}=0.22, \mathrm{p}<0.003$ and $\mathrm{DC}=2.92, \mathrm{Ml}=0.16, \mathrm{p}<0.014$, respectively).

Peculiarities of the function of attention in patients with Cls in DDs are reflected in Table 3, from which it can be seen that the concentration was reduced in the majority of the patients with RDD $(36.59 \pm 2.39) \%$, was of medium or below medium levels in patients with BAD $(33.33 \%$ and $30.50 \%$, respectively) and of a medium level in most patients with PDR $(42.86 \pm 3.34) \%$. Attention span was characterized by a predominance of a medium level in patients with RDD $(42.28 \pm 2.63) \%$ and PDR $(40.82 \pm 3.24) \%$, and a reduced level $(48.23 \pm 2.48) \%$ in most patients with BAD. The switching of attention

Table 2

\section{Levels of a delayed reproduction in patients with DDs}

таблица 2

Уровни отсроченного воспроизведения у пациентов с депрессивными расстройствами

\begin{tabular}{|l|l|l|l|l|l|l|}
\hline \multirow{2}{*}{ Levels } & \multicolumn{2}{l|}{ RDR $(\mathbf{n}=\mathbf{1 2 3})$} & \multicolumn{2}{l|}{ BAD $(\mathbf{n = 1 4 1 )}$} & \multicolumn{2}{l|}{ PDR $(\mathbf{n = 9 8 )}$} \\
\cline { 2 - 8 } & $\mathbf{n}$ & $\mathbf{\%} \pm \mathbf{m}$ & $\mathbf{n}$ & $\mathbf{\%} \pm \mathbf{m}$ & $\mathbf{n}$ & \% $\pm \mathbf{m}$ \\
\hline High level & 47 & $38.21 \pm 2.46$ & 36 & $25.53 \pm 1.57$ & 57 & $58.16 \pm 3.88$ \\
\hline Medium level & 62 & $50.41 \pm 2.91$ & 70 & $49.65 \pm 2.52$ & 28 & $28.57 \pm 2.49$ \\
\hline Below medium level & 12 & $9.76 \pm 0.76$ & 31 & $21.99 \pm 1.39$ & 11 & $11.22 \pm 1.09$ \\
\hline Low level & 2 & $1.63 \pm 0.13$ & 4 & $2.84 \pm 0.20$ & 2 & $2.04 \pm 0.21$ \\
\hline
\end{tabular}


in most patients with RDD (43.09 \pm 2.66$) \%$ and PDR (44.90 \pm 3.44$) \%$ was below medium, whereas in patients with BAD it was of medium and low levels (34.04\% and $34.75 \%$ respectively).

The statistical analysis revealed that the level of concentration was higher in patients with PDR than in patients with $\mathrm{RDD}(\mathrm{DC}=3.62, \mathrm{Ml}=0.11, \mathrm{p}<0.044)$ and $B A D(D C=5.97, M l=0.25, p<0.007)$, among them there were more persons with low and below medium levels of concentration, in contrast to patients with PDR ( $\mathrm{DC}=2.99, \mathrm{Ml}=0.12, \mathrm{p}<0.032$ and $\mathrm{DC}=3.70, \mathrm{Ml}=0.20, \mathrm{p}<0.008$, respectively, and $\mathrm{DC}=5.55, \mathrm{Ml}=0.73, \mathrm{p}<0.0001$ and $\mathrm{DC}=4.75, \mathrm{Ml}=0.48$, $\mathrm{p}<0.0001$, respectively). Patients with $B A D$ had a higher level of attention switching as compared with patients with $\mathrm{RDD}(\mathrm{DC}=10.20, \mathrm{Ml}=0.39, \mathrm{p}<0.002)$, while among patients with RDD and PDR there were more persons with below medium or low levels of attention switching compared with patients with $B A D(D C=0.93, M l=0.04, p<0.038$ and $D C=1.11, M l=0.06, p<0.030$, respectively, and $\mathrm{DC}=5.36, \mathrm{Ml}=0.51, \mathrm{p}<0.0001$ and $\mathrm{DC}=3.47, \mathrm{Ml}=0.17$, $\mathrm{p}<0.013$, respectively). The prevalence of high and above medium levels of attention span was characteristic for patients with PDR, in contrast to patients with $B A D$ ( $D C=5.97, \mathrm{Ml}=0.25, \mathrm{p}<0.007$ and $\mathrm{DC}=6.51, \mathrm{Ml}=0.72, \mathrm{p}<0.0001$, respectively), among them there were more persons with a reduced level of attention span $(\mathrm{DC}=5.61, \mathrm{Ml}=0.98, \mathrm{p}<0.0001)$. The predominance of medium and above medium levels of attention span was difference between patients with RDD and patients with $B A D(D C=1.03, M l=0.05, p<0.033$ and $D C=6.37$, $\mathrm{Ml}=0.68, \mathrm{p}<0.0001$, respectively), among them there were more patients

\section{Table 3}

Peculiarities of the function of attention in patients with DDs (according to the Dot Cancellation Test)

Таблица 3

Особенности функции внимания у пациентов с депрессивными расстройствами

\begin{tabular}{|c|c|c|c|c|c|c|}
\hline \multirow{2}{*}{ Parameters } & \multicolumn{2}{|c|}{ RDD (n=123) } & \multicolumn{2}{|c|}{$\operatorname{BAD}(n=141)$} & \multicolumn{2}{|c|}{ PDR (n=98) } \\
\hline & $\mathbf{n}$ & $\% \pm m$ & $\mathbf{n}$ & $\% \pm m$ & $\mathbf{n}$ & $\% \pm m$ \\
\hline \multicolumn{7}{|l|}{ Concentration } \\
\hline High level & 6 & $4.88 \pm 0.39$ & 4 & $2.84 \pm 0.20$ & 11 & $11.22 \pm 1.09$ \\
\hline Above medium & 18 & $14.63 \pm 1.11$ & 20 & $14.18 \pm 0.94$ & 27 & $27.55 \pm 2.42$ \\
\hline Medium level & 34 & $27.64 \pm 1.93$ & 47 & $33.33 \pm 1.94$ & 42 & $42.86 \pm 3.34$ \\
\hline Below medium & 45 & $36.59 \pm 2.39$ & 43 & $30.50 \pm 1.82$ & 10 & $10.20 \pm 1.00$ \\
\hline Low & 20 & $16.26 \pm 1.22$ & 27 & $19.15 \pm 1.23$ & 8 & $8.16 \pm 0.81$ \\
\hline \multicolumn{7}{|c|}{ Switching of attention } \\
\hline High level & 1 & $0.81 \pm 0.07$ & 12 & $8.51 \pm 0.58$ & 4 & $4.08 \pm 0.41$ \\
\hline Above medium & 9 & $7.32 \pm 0.58$ & 21 & $14.89 \pm 0.98$ & 7 & $7.14 \pm 0.71$ \\
\hline Medium level & 27 & $21.95 \pm 1.59$ & 48 & $34.04 \pm 1.97$ & 26 & $26.53 \pm 2.34$ \\
\hline Below medium & 53 & $43.09 \pm 2.66$ & 49 & $34.75 \pm 2.01$ & 44 & $44.90 \pm 3.44$ \\
\hline Low & 33 & $26.83 \pm 1.88$ & 11 & $7.80 \pm 0.54$ & 17 & $17.35 \pm 1.63$ \\
\hline \multicolumn{7}{|l|}{ Attention span } \\
\hline High level & 9 & $7.32 \pm 0.58$ & 4 & $2.84 \pm 0.20$ & 11 & $11.22 \pm 1.09$ \\
\hline Above medium & 34 & $27.64 \pm 1.93$ & 9 & $6.38 \pm 0.44$ & 28 & $28.57 \pm 2.49$ \\
\hline Medium level & 52 & $42.28 \pm 2.63$ & 47 & $33.33 \pm 1.94$ & 40 & $40.82 \pm 3.24$ \\
\hline Below medium & 18 & $14.63 \pm 1.11$ & 68 & $48.23 \pm 2.48$ & 13 & $13.27 \pm 1.27$ \\
\hline Low & 10 & $8.13 \pm 0.64$ & 13 & $9.22 \pm 0.63$ & 6 & $6.12 \pm 0.61$ \\
\hline
\end{tabular}


with a reduced level of attention span $(D C=5.18, M l=0.87, p<0.0001)$. Thus, patients with RDD had difficulties to take their minds off their own thoughts, they were focused on their own experiences, and things happening around them did not attract their attention. Patients with PDR were characterized by a greater concentration, patients with BAD were characterized by a greater level of attention switching, and patients with RDD were characterized by a greater attention span.

The peculiarities of executive functions in patients with DDs were defined using the Trial Making Test (TMT) and the Verbal Fluency Test (VFT). It was found out, that the majority of patients with RDD $(39.84 \pm 2.53) \%$ and BAD $(41.13 \pm 2.25) \%$ had moderate impairments of a visual-motor coordination, the majority of patients with PDR had no impairments of a visual-motor coordination $(45.92 \pm 3.48) \%, 36.73 \%$ of them had mild such impairments (Table 4). Most patients with RDD $(54.47 \pm 3.01) \%$ and BAD $(65.96 \pm 2.75) \%$ had a moderate level, and most patients with PDR $(66.33 \pm 3.97) \%$ had slightly impaired executive functions.

The mathematical analysis of the results showed that among patients with PDR there were more persons with the no or slight impairments of visual-motor coordination as compared with patients with $\mathrm{RDD}(\mathrm{DC}=3.72$, $\mathrm{Ml}=0.49, \mathrm{p}<0.0001$ and $\mathrm{DC}=240, \mathrm{Ml}=0.19, \mathrm{p}<0.004$, respectively) and $\mathrm{BAD}$ ( $D C=6.35, \mathrm{Ml}=1.12, \mathrm{p}<0.0001$ and $\mathrm{DC}=2.23, \mathrm{Ml}=0.16, \mathrm{p}<0.005$, respectively), among them there were more patients with moderate $(D C=5.50$, $\mathrm{Ml}=0.79, \mathrm{p}<0.0001$ and $\mathrm{DC}=5.64, \mathrm{Ml}=0.84, \mathrm{p}<0.0001$, respectively) and significant $(D C=5.03, M l=0.34, p<0.0021$ and $D C=6.32, M l=0.64, p<0.0001$, respectively) impairments of visual-motor coordination. Along with this, it was demonstrated that there were more persons with no impairments of visual-motor coordination among patients with RDD than among patients with $B A D(D C=2.63, M l=0.12, p<0.0182$ ). Among patients with PDR, there were more persons with no or slight impairments of executive functions as compared with patients with $\mathrm{RDD}(\mathrm{DC}=2.30, \mathrm{Ml}=0.11, \mathrm{p}<0.0258$ and $\mathrm{DC}=5.51, \mathrm{Ml}=1.31, \mathrm{p}<0.0001$, respectively) and $\mathrm{BAD}(\mathrm{DC}=7.42, \mathrm{Ml}=0.71$, $\mathrm{p}<0.0001$ and $\mathrm{DC}=8.92, \mathrm{Ml}=2.58, \mathrm{p}<0.0001$, respectively), among them

\section{Table 4}

\section{Parameters of a visual-motor coordination and executive function in patients with DDs}

таблица 4

Параметры зрительно-моторной координации и исполнительной функции у пациентов с депрессивными расстройствами

\begin{tabular}{|c|c|c|c|c|c|c|}
\hline \multirow{2}{*}{ Parameters } & \multicolumn{2}{|c|}{$\operatorname{RDD}(n=123)$} & \multicolumn{2}{|c|}{$\operatorname{BAD}(n=141)$} & \multicolumn{2}{|c|}{ PDR $(n=98)$} \\
\hline & $\mathbf{n}$ & $\% \pm m$ & $\mathbf{n}$ & $\% \pm m$ & n & $\% \pm m$ \\
\hline \multicolumn{7}{|c|}{ TMT-A (visual-motor coordination) } \\
\hline No impairments & 24 & $19.51 \pm 1.43$ & 15 & $10.64 \pm 0.72$ & 45 & $45.92 \pm 3.48$ \\
\hline Low level of impairments & 26 & $21.14 \pm 1.54$ & 31 & $21.99 \pm 1.39$ & 36 & $36.73 \pm 3.01$ \\
\hline Moderate level of impairments & 49 & $39.84 \pm 2.53$ & 58 & $41.13 \pm 2.25$ & 11 & $11.22 \pm 1.09$ \\
\hline Significant level of impairments & 24 & $19.51 \pm 1.43$ & 37 & $26.24 \pm 1.61$ & 6 & $6.12 \pm 0.61$ \\
\hline \multicolumn{7}{|l|}{ TMT-B (executive functions) } \\
\hline No impairments & 17 & $13.82 \pm 1.05$ & 6 & $4.26 \pm 0.30$ & 23 & $23.47 \pm 2.12$ \\
\hline Low level of impairments & 23 & $18.70 \pm 1.38$ & 12 & $8.51 \pm 0.58$ & 65 & $66.33 \pm 3.97$ \\
\hline Moderate level of impairments & 67 & $54.47 \pm 3.01$ & 93 & $65.96 \pm 2.75$ & 7 & $7.14 \pm 0.71$ \\
\hline Significant level of impairments & 16 & $13.01 \pm 0.99$ & 30 & $21.28 \pm 1.35$ & 3 & $3.06 \pm 0.31$ \\
\hline
\end{tabular}


persons with moderate $(\mathrm{DC}=8.82, \mathrm{Ml}=2.09, \mathrm{p}<0.0001$ and $\mathrm{DC}=9.65, \mathrm{Ml}=2.84$, $\mathrm{p}<0.0001$, respectively) and significant $(\mathrm{DC}=6,28 \mathrm{Ml}=0.31, \mathrm{p}<0.005$ and $\mathrm{DC}=8.42, \mathrm{Ml}=0.77, \mathrm{p}<0.0001$, respectively) impairments of executive functions prevailed. It was also showed, that there were more persons with no or a low level of impairments of executive functions among patients with RDD than among patients with $B A D(D C=5.12, M l=0.24, p<0.004$ and $D C=3.42, \mathrm{Ml}=0.17, \mathrm{p}<0.007$, respectively),

The Verbal Fluency Test (VFT) was used to assess a verbal associative productivity and a lexical system functioning in patients with DDs. The analysis of a verbal associative productivity showed that a moderate level of impairments in the associative fluency was established in the majority of patients with RDD $(58.54 \pm 3.09) \%$ and BAD $(58.16 \pm 2.69) \%$, and a low level of impairments of an associative productivity $(58.16 \pm 3.88) \%$ was revealed in the majority of patients with PDR (Table 5).

The functioning of the lexical system, the ability to actively search for the necessary information in memory were somewhat reduced in patients with DDs. In particular, the group with RDD was characterized by a significant slowdown in the pace of task completion closer to its end due to a poor motivational component and a mental depletion: $39.84 \%$ of patients had a moderate level of impairments, $32.52 \%$ of patients had significant one, and $23.58 \%$ of patients had a low level of impairments of a lexical system functioning and executive functions. The majority of patients with BAD had moderate and significant impairments of a lexical system functioning and executive functions ( $47.52 \%$ and $39.01 \%$, respectively). In the majority of patients with PDR, mild impairments of a lexical system functioning and executive functions $(45.92 \pm 3.48) \%$ or an absence of such impairments $(31.63 \pm 2.70) \%$ were recorded.

A comparison of the results showed that an absence or a low level of impairments of the verbal associative productivity occurred more often among patients with PDR as compared with patients with RDD ( $D C=3.38$, $\mathrm{Ml}=0.24, \mathrm{p}<0.0035$ and $\mathrm{DC}=4.23, \mathrm{Ml}=0.77, \mathrm{p}<0.0001$, respectively) and $\mathrm{BAD}$

Table 5

Parameters of a verbal associative productivity and a lexical system functioning in patients with DDs

Таблица 5

Параметры вербальной ассоциативной продуктивности и функционирования лексической системы у пациентов с депрессивными расстройствами

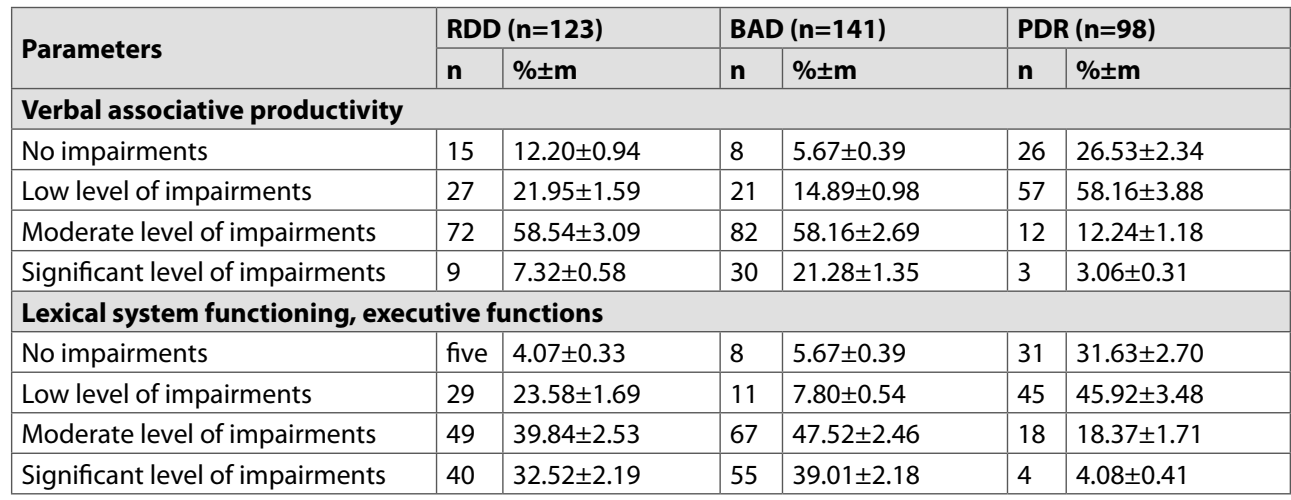


( $D C=6,70, M l=0.70, p<0.004$ and $D C=5.92, M l=1.28, p<0.0001$, respectively), among them there were more persons with a moderate level of impairments of the associative productivity $(\mathrm{DC}=6.79, \mathrm{Ml}=1.57, \mathrm{p}<0.004$ and $\mathrm{DC}=6.77$, $\mathrm{Ml}=1.55, \mathrm{p}<0.0001$, respectively). The number of persons with significant impairments of the verbal associative productivity was higher among patients with BAD as compared with patients with RDD and PDR (DC=4.64, $\mathrm{Ml}=0.32, \mathrm{p}<0.0007$ and $\mathrm{DC}=8.42, \mathrm{Ml}=0.77, \mathrm{p}<0.0001$ respectively). It should be pointed out, that the number of patients with no impairments and a low level of impairments was higher among patients with RDD as compared with patients with $B A D(D C=3.32, \mathrm{Ml}=0.11, \mathrm{p}<0.0309$ and $\mathrm{DC}=1.68, \mathrm{Ml}=0.06$, $\mathrm{p}<0.0427$, respectively).

The absence of impairments or a low level of impairments of a lexical system functioning and executive functions occurred more often in patients with PDR than in patients with $\mathrm{RDD}(\mathrm{DC}=8.91, \mathrm{Ml}=1.23, \mathrm{p}<0.0001$ and $D C=2.89, \mathrm{Ml}=0,32, \mathrm{p}<0.0002$, respectively) and $\mathrm{BAD}(\mathrm{DC}=7.46, \mathrm{Ml}=0.97$, $\mathrm{p}<0.0001$ and $\mathrm{DC}=7.70, \mathrm{Ml}=1.47, \mathrm{p}<0.0001$, respectively), among them there was a predominance of persons with moderate and significant levels of a lexical system functioning and executive functions, in $\operatorname{RDD}(D C=3.36$, $\mathrm{Ml}=0.36, \mathrm{p}<0.0002$ and $\mathrm{DC}=9.01, \mathrm{Ml}=1.28, \mathrm{p}<0.0001$, respectively) and in $B A D(D C=4.13, M l=0.60, p<0.0001$ and $D C=9.80, M l=1.71, p<0.0001$, respectively). It should also be noted, that the number of persons with moderate impairments of a lexical system functioning and executive functions was higher among patients with $B A D$ as compared with patients with $\mathrm{RDD}(\mathrm{DC}=0.77, \mathrm{Ml}=0.03 \mathrm{p}<0.0453)$, among them persons with mild impairments of a lexical system functioning and executive functions prevailed ( $\mathrm{DC}=4.80, \mathrm{Ml}=0.38, \mathrm{p}<0.0002$ ).

Based on the calculation of $\mathrm{DC}$ and $\mathrm{MI}$, differentiated diagnostic criteria and target markers of Cls in DDs were defined. They are given in Table 6.

On the basis of the identified diagnostic markers, a comprehensive therapy of $\mathrm{Cls}$ (CTCl) in DDs was worked out. This therapy is based on

\section{Table 6}

\section{Differentiated diagnostic target markers of cognitive impairments in DDs}

\section{Таблица 6}

Дифференцированные диагностические целевые маркеры когнитивных нарушений при депрессивных расстройствах

\begin{tabular}{|c|c|c|c|}
\hline Names of spheres & Parameter & DC & MI \\
\hline \multicolumn{4}{|c|}{ Cognitive target markers in RDD } \\
\hline \multirow{6}{*}{ Sphere of thought } & Decreased interest & 2.24 & 0.45 \\
\hline & Difficulties with decision making & 1.61 & 0.23 \\
\hline & Difficulties with abstractions & 3.97 & 0.46 \\
\hline & Rigidity of thinking & 2.59 & 0.46 \\
\hline & Hypochondriacal ideas & 1.53 & 0.12 \\
\hline & Obsessive thoughts & 2.11 & 0.25 \\
\hline \multirow{2}{*}{ Mnestic sphere } & Reduced short-term memory & 2.67 & 0.13 \\
\hline & Moderate impairments of a delayed reproduction & 2.47 & 0.27 \\
\hline \multirow{4}{*}{ Executive functions } & Moderate to significant impairments of a visual-motor coordination & 5.03 & 0.34 \\
\hline & Moderate to significant impairments of executive functions & 6.28 & 0.31 \\
\hline & Moderate to significant impairments of a lexical system & 9.01 & 1.28 \\
\hline & Moderate impairments of a verbal productivity & 6.79 & 1.57 \\
\hline
\end{tabular}




\begin{tabular}{|c|c|c|c|}
\hline \multirow{5}{*}{ Sphere of attention } & Below medium to low levels of concentration & 5.55 & 0.73 \\
\hline & Below medium to low levels of attention switching & 5.36 & 0.51 \\
\hline & Reduced level of work efficiency & 3.11 & 0.35 \\
\hline & Medium level of attention span & 1.03 & 0.05 \\
\hline & Below medium to low levels of workability & 8.04 & 1.10 \\
\hline \multicolumn{4}{|c|}{ Cognitive target markers in BAD } \\
\hline \multirow{7}{*}{ Sphere of thought } & Depletion of the mental activity & 1.52 & 0.20 \\
\hline & Paranoid disorders & 5.94 & 0.28 \\
\hline & Reduced abstract thinking & 3.65 & 0.37 \\
\hline & Decreased interest & 2.35 & 0.65 \\
\hline & Increased sensitivity to criticism & 2.11 & 0.09 \\
\hline & Difficulties with decision making & 1.10 & 0.10 \\
\hline & Ideas of inferiority & 2.42 & 0.15 \\
\hline \multirow{2}{*}{ Mnestic sphere } & Reduced level of a delayed reproduction & 3.53 & 0.22 \\
\hline & Reduced short-term memory & 2.13 & 0.08 \\
\hline \multirow{4}{*}{ Executive functions } & Moderate to significant impairments of a visual-motor coordination & 6.32 & 0.64 \\
\hline & Moderate to significant impairments of executive functions & 8.42 & 0.77 \\
\hline & Moderate to significant impairments of a lexical system & 9.80 & 1.71 \\
\hline & Moderate to significant impairments of a verbal productivity & 6.77 & 1.55 \\
\hline \multirow{6}{*}{ Sphere of attention } & Below medium to low levels of concentration & 4.75 & 0.48 \\
\hline & Medium to below medium levels of attention switching & 3.09 & 0.12 \\
\hline & Low level of work efficiency & 3.46 & 0.45 \\
\hline & Below medium level of attention span & 5.61 & 0.98 \\
\hline & Below medium to low levels of workability & 3.47 & 0.11 \\
\hline & Low level of a mental stability & 6.48 & 0.57 \\
\hline \multicolumn{4}{|c|}{ Cognitive target markers in PDR } \\
\hline \multirow{4}{*}{ Sphere of thought } & Obsessive thoughts & 2.34 & 0.12 \\
\hline & Suicidal thoughts & 0.99 & 0.07 \\
\hline & Hypochondriacal ideas & 2.11 & 0.25 \\
\hline & Increased sensitivity to criticism & 1.26 & 0.13 \\
\hline Mnestic sphere & High level of a delayed reproduction & 1.82 & 0.18 \\
\hline \multirow{4}{*}{ Executive functions } & Mild impairments of a visual-motor coordination & 2.40 & 0.19 \\
\hline & Mild impairments of executive functions & 5.51 & 1.31 \\
\hline & Mild impairments of a lexical system & 2.89 & 0.32 \\
\hline & Mild impairments of a verbal productivity & 4.23 & 0.77 \\
\hline \multirow{6}{*}{ Sphere of attention } & Medium level of concentration & 1.90 & 0.14 \\
\hline & Below medium to low levels of attention switching & 3.47 & 0.17 \\
\hline & Medium to above medium levels of work efficiency & 5.10 & 0.32 \\
\hline & Medium to above medium levels of attention span & 6.51 & 0.72 \\
\hline & Medium level of workability & 2.21 & 0.17 \\
\hline & Medium level of a mental stability & 1.58 & 0.09 \\
\hline
\end{tabular}

the principles of an integrated, personal-oriented and differentiated approach, ensuring the staging, sequence, and optimality of treatment and rehabilitation measures. Its goals were: to reduce $\mathrm{Cls}$, to reduce depressive manifestations, to change pathological cognitive patterns associated with the presence of depressive disorders, to maximize recovery of patients' work 
capacity and social functioning (SF), to prevent a suicidal behavior and DD relapses, to prevent a chronicity of $\mathrm{Cls}$, to provide an early reintegration and a social adjustment of patients, to improve patients' quality of life and SF. The proposed CTCI was realized in four stages: diagnostic, therapeutic, rehabilitation and prevention. The diagnostic stage included a clinical and psychopathological assessment of patients' cognitive disorders, an analysis of their anamnestic data, clinical symptoms, dynamics and prognosis of the disease, the relationship between clinical and socio-psychological factors. This resulted in development of an action plan for the correction of $\mathrm{Cls}$, elimination of manifestations of DDs, a patient's adjustment and readjustment. The therapeutic stage was implemented by means of a complex of pharmacotherapeutic and psychotherapeutic measures to correct Cls, to stop DDs, to normalize psychoemotional conditions, a patient's social adjustment and readjustment. The pharmacotherapy at this stage is aimed at correcting $\mathrm{Cls}$ and reducing depressive symptoms. Psychotherapeutic and rehabilitation interventions imply a combination of psychoeducational activities, the cognitive-behavioral psychotherapy, and training of cognitive functions. The duration of this stage is 1-2 months. The rehabilitation stage included a set of pharmacotherapeutic and psychotherapeutic measures aimed at restoring cognitive functions, consolidating the effect of antidepressant therapy, and restoring a patient's SF. At this stage, a differentiated psychotherapeutic work with patients continues, it consists in a combination of the cognitive-behavioral psychotherapy, training of effective coping strategies and a communication training. Measures for social rehabilitation and readjustment of a patient are also of particular importance. A social rehabilitation provides for measures to support patients in terms of social-environmental and socialdomestic issues in order to restore lost and to form new social liaisons and relationships. The rehabilitation stage can begin already at the stage of the inpatient treatment (if a reduction of depressive symptoms is achieved) and lasts during 3-12 months after discharge from the hospital. The pharmacotherapy at the rehabilitation stage is similar to that used at the therapeutic stage, with an appropriate adjustment of the medication dosage depending on patient's actual conditions. The prevention stage is designed to maintain normal psychoemotional conditions, to resist stress effectively, and to prevent the recurrence of the depressive disorder. This stage is focused on a long time (up to 2 years). The pharmacotherapy at this stage includes the treatment of the underlying disease in DDs and the prevention of recurrence of depressions. The psychotherapy is represented mainly by self-regulation techniques aimed at the self-control of emotional conditions and at prevention of recurrence of depression.

An approbation of the $\mathrm{CTCl}$ involved 190 patients with $\mathrm{Cls}$ in DDs, including 97 persons, who completed the CTCl course according to the developed program (the main group), and 93 persons, who were treated in accordance with the traditional scheme (the control group). A comparative evaluation of effectiveness of the $\mathrm{CTCl}$ and the traditional approach was carried out by comparing data from clinical-psychological and psychometric examinations. Criteria of effectiveness for CTCl were: clinical dynamics of DDs; the degree of improvement/deterioration of cognitive functions (deterioration, no effect, minimal improvement, moderate improvement); 
the level of a social functioning and the degree of recovery of the everyday life functions. Table 7 shows the significant changes identified as a result of treatment in both groups. The clinical dynamics of the mental health conditions in patients of the main group after CTCl was determined by a significant reduction of objective and subjective signs of depression, a decreased internal tension, sleep and concentration improvements, a reduction of apathy, pessimistic and suicidal thoughts. The patients of the control group demonstrated a reduction of objective signs of depression and internal tension, an appetite amelioration, a reduction of apathy and suicidal thoughts. An assessment of the dynamics of cognitive functions showed that in most patients of the main group (50.52\%), after treatment according to the developed $\mathrm{CTCl}$, a moderate improvement of cognitive functions was determined $(D C=3.10, M l=0.40)$, in most patients of the control group $(50,54 \%)$ there was a minimal improvement in cognitive functions ( $D C=1.11, \mathrm{Ml}=0.06$ ) and in $18.28 \%$ of patients there was no effect $(D C=3.46, M l=0.17$ ). The dynamics of $S F$ in patients of the main group was determined by a significant reduction of impairments in the spheres of socially useful activity, personal and social relationships, and self-care and by a reduction of aggressive behavioral patterns. In patients of the control group, positive dynamics of their SF in the spheres of self-care, personal and social relationships was determined.

Table 7

Dynamics of clinical-psychopathological characteristics of patients with cognitive impairment in DDs

Таблица 7

Динамика клинико-психопатологических характеристик пациентов с когнитивными нарушениями при депрессивных расстройствах

\begin{tabular}{|c|c|c|c|}
\hline \multirow{2}{*}{$\begin{array}{l}\text { Criteria of } \\
\text { evaluation }\end{array}$} & \multirow[t]{2}{*}{ Indicators } & $\begin{array}{l}\text { Main } \\
\text { group }\end{array}$ & $\begin{array}{l}\text { Control } \\
\text { group }\end{array}$ \\
\hline & & \multicolumn{2}{|l|}{$\mathbf{R}$} \\
\hline \multirow{9}{*}{$\begin{array}{l}\text { Clinical dynamics of } \\
\text { depressive disorders }\end{array}$} & Reduction of objective signs of depression & 0.0237 & 0.0413 \\
\hline & Reduction of subjective signs of depression & 0.0163 & \\
\hline & Reduction of internal tension & 0.0012 & 0.0258 \\
\hline & Improvement of sleep & 0.0381 & \\
\hline & Amelioration of appetite & & 0.0143 \\
\hline & Improvement of concentration & 0.0025 & \\
\hline & Reduction of apathy & 0.0001 & 0.0253 \\
\hline & Reduction of pessimistic thoughts & 0.0015 & \\
\hline & Reduction of suicidal thoughts & 0.0256 & 0.0162 \\
\hline \multirow{3}{*}{$\begin{array}{l}\text { Dynamics of } \\
\text { cognitive functions }\end{array}$} & Moderate improvement of cognitive functions & 0.0001 & \\
\hline & Minimal improvement of cognitive functions & & 0.0339 \\
\hline & No effect & & 0.0216 \\
\hline \multirow{4}{*}{$\begin{array}{l}\text { Dynamics of a social } \\
\text { functioning }\end{array}$} & $\begin{array}{l}\text { Reduction of impairments in the sphere of a socially } \\
\text { useful activity }\end{array}$ & 0.0347 & \\
\hline & $\begin{array}{l}\text { Reduction of impairments in the sphere of personal and } \\
\text { social relationships }\end{array}$ & 0.0136 & 0.0362 \\
\hline & Reduction of impairments in self-care & 0.0409 & 0.0453 \\
\hline & Reduction of aggressive behavioral patterns & 0.0251 & \\
\hline
\end{tabular}




\section{- CONCLUSIONS}

This study has defined and proved that the structure of cognitive impairments in patients with DDs is determined by dysfunctions of cognitive processes (thinking, memory, attention) and executive functions, which are differentiated depending on the form of DD.

The structure of $\mathrm{Cls}$ in patients with RDD was distinguished by the following dysfunctions:

- in the sphere of thinking: decreased interest $(99.19 \%, D C=2.24$, $\mathrm{Ml}=0.45)$, difficulties of decision making $(90.24 \%, \mathrm{DC}=1.61, \mathrm{Ml}=0.23)$ and abstraction $(38.21 \%, \mathrm{DC}=3.97, \mathrm{Ml}=0.46)$, rigidity of thinking $(79.67 \%$, $\mathrm{DC}=2.59, \mathrm{Ml}=0.46$ );

- in the mnestic sphere: a reduced level of the short-term memory (4.32 points, $p<0.025$ ) and the prevalence of moderate impairments of a delayed reproduction $(50.41 \%, \mathrm{DC}=2.47, \mathrm{Ml}=0.27)$;

- in the sphere of executive functions: the presence of moderate impairments of a visual-motor coordination $(39.84 \%, \mathrm{DC}=5.50, \mathrm{Ml}=0.79)$, visual-spatial functions (13.72 points, $D C=6.28, M l=0.31$ ), executive functions $(54.47 \%, \mathrm{DC}=8.82, \mathrm{Ml}=2.09)$, executive function of a lexical system $(39.84 \%, \mathrm{DC}=3.36, \mathrm{Ml}=0.36)$, and verbal productivity $(58.54 \%$, $\mathrm{DC}=6.79, \mathrm{Ml}=1.57$;

- in the sphere of attention: a decreased concentration (80.49\%, DC=2.99, $\mathrm{Ml}=0.12)$ and attention switching $(43.09 \%, \mathrm{DC}=0.93, \mathrm{Ml}=0.04)$, a medium level of attention span $(42.28 \%, \mathrm{DC}=1.03, \mathrm{Ml}=0.05)$.

The structure of $\mathrm{Cls}$ in patients with $\mathrm{BAD}$ included the following dysfunctions:

- in the sphere of thinking: depletion of mental processes $(90.07 \%$, $D C=1.52, M l=0.20)$, decreased interest $(75.89 \%, D C=2.35, M l=0.65)$, increased sensitivity to criticism $(73.76 \%, \mathrm{DC}=2.11, \mathrm{Ml}=0.09)$, difficulties of decision making $(70.21 \%, \mathrm{DC}=1.10, \mathrm{Ml}=0.10)$, ideas of inferiority (68.79\%, DC=0.58, $\mathrm{Ml}=0.03$ );

- in the mnestic sphere: a reduced level of the short-term memory (4.52 points, $\mathrm{DC}=2.13, \mathrm{Ml}=0.08$ ) and the predominance of a medium level of a delayed reproduction ( $49.65 \%, \mathrm{DC}=2.40, \mathrm{Ml}=0.25)$;

- in the sphere of executive functions: the presence of moderate impairments of a visual-motor coordination $(41.13 \%, \mathrm{DC}=5.64, \mathrm{Ml}=0.84)$, executive functions $(65.96 \%, \mathrm{DC}=9.65, \mathrm{Ml}=2,84)$, executive functions of a lexical system $(47.52 \%, \mathrm{DC}=4.13, \mathrm{Ml}=0.60)$, and verbal productivity (58.16\%, DC=6.77, Ml=1.55);

- in the sphere of attention: a decreased concentration $(93.62 \%, \mathrm{DC}=3.70$, $\mathrm{Ml}=0.20)$, attention switching $(34.75 \%, \mathrm{DC}=1.91, \mathrm{Ml}=0.12)$, and attention span $(48,23 \%, \mathrm{DC}=5.18, \mathrm{Ml}=0.87)$.

The structure of $\mathrm{Cls}$ in patients with PDR was determined by the presence of the following dysfunctions:

- in the sphere of thinking: obsessive $(85.71 \%, \mathrm{DC}=1.43, \mathrm{Ml}=0.17)$ and suicidal (73.47\%, $\mathrm{DC}=0.99, \mathrm{Ml}=0.07)$ thoughts, hypochondriacal ideas $(62,24 \%$, $\mathrm{DC}=2.11, \mathrm{Ml}=0.25)$, increased sensitivity to criticism $(82.65 \%$, $\mathrm{DC}=1.26$, $\mathrm{Ml}=0.13)$, difficulties of decision making $(62,24 \%, \mathrm{DC}=1.61, \mathrm{Ml}=0.23)$;

- in the mnestic sphere: a normative level of the short-term memory (5.37 points, $\mathrm{p}<0.025)$ and the predominance of a high level of a delayed reproduction $(58.16 \%, \mathrm{DC}=1.82, \mathrm{Ml}=0.18)$; 
- in the sphere of executive functions: the presence of mild impairments of a visual-motor coordination $(36.73 \%, \mathrm{DC}=2.40, \mathrm{Ml}=0.19)$, executive functions $(66.33 \%, D C=5.51, M l=1,31)$, executive functions of a lexical system $(45.92 \%, \mathrm{DC}=2.89, \mathrm{Ml}=0.32)$, and verbal productivity $(58.16 \%$, $\mathrm{DC}=4.23, \mathrm{Ml}=0.77$;

- in the sphere of attention: a medium level of concentration $(42.86 \%$, $\mathrm{DC}=1.90, \mathrm{Ml}=0.14)$, the prevalence of a below medium level of attention switching $(44.90 \%, \mathrm{DC}=1.11, \mathrm{Ml}=0,06)$, a medium level of attention span $(40.82 \%, \mathrm{DC}=6.51, \mathrm{Ml}=0.72)$.

It has been proven the effectiveness of the proposed scheme of the $\mathrm{CPCl}$ in patients with DDs. Its effect consists in a significant reduction of clinical manifestations of DDs (a reduction of objective and subjective signs of depression $(p<0.0237)$, a decreased internal tension $(p<0.0012)$, an improvement of sleep $(p<0,0381))$, moderate improvements of cognitive functions $(D C=3.10, M l=0.40, p<0.0001)$, social functioning in the main life spheres (a socially useful activity $(p<0.0347)$, personal and social relationships $(p<0.0136)$, a reduction of impairments of self-care $(p<0.0409)$, a reduction of aggressive behavioral patterns $(p<0.0251)$ ).

Thus, the study resulted in identification of peculiarities of $\mathrm{Cls}$ in various types of DDs, which can serve as diagnostic criteria for differential diagnosis and determining the tactics of pharmacotherapy and rehabilitation. The developed CTCI for DDs has demonstrated its effectiveness and can be used in psychocorrectional measures aimed at treating this group of patients.

\section{REFERENCES}

Brzezicka A. (2013) Integrative deficits in depression and in negative mood states as a result of fronto-parietal network dysfunctions. Acta Neurobiol Exp, no 73, pp. 313-325. Fehnel SE, Forsyth BH, DiBenedetti DB (2016) Patient-centered assessment of cognitive symptoms of depression. CNS Spectr, vol. 21, no 1, pp. 43-52. Cusi A., Nazarov A., Holshausen K., Macqueen G., McKinnon M. (2012) Systematic review of the neural basis of social cognition in patients with mood disorders. J Psychiatry Neurosci., vol. 37, no 3, pp. 154-169.

Iverson GL, Lam RW. (2013) Rapid screening for perceived cognitive impairment in major depressive disorder. Ann Clin Psychiatry, vol. 25, no 2, pp. 135-40.

5. McIntyre RS, Lophaven S, Olsen CK. (2014) A randomized, double-blind, placebo-controlled study of vortioxetine on cognitive function in depressed adults. Int $J$ Nerropsych

Neuropsychopharmacol, vol. 17, no 10, pp. 1557-67. Azimova YuE. (2017) Depressiya i kognitivnyye narusheniya: opyt ispol'zovaniya vortiokse
experience with vortioxetine in neurological practice]. Meditsinskiy sovet, no 11, pp. 36-39.

7. McIntyre RS., Cha DS., Soczynska JK. (2013) Cognitive deficits and functional outcomes in major depressive disorder: determinants, substrates, and treatment interventions. Depress. Anxiety, vol. 30, no 6, pp. 515-527.

8. Roiser JP., Sahakian BJ. (2013) Hot and cold cognition in depression. CNS Spectr, vol. 18, no 3, pp. 139-149.

9. Shmukler $A B$ (2016) Kognitivnyye narusheniya $v$ strukture depressivnogo sindroma [Cognitive impairments in the structure of depressive syndrome]. Sotsial'naya klinicheskaya psikhiatriya, vol. 26, no 1, pp. 72-76. Available at: https://cyberleninka.ru/article/n/kognitivnye-narusheniya-v-strukture-depressivnogo-sindroma

10. Maruta NO., Panko TV., Kalenska HYu. (2018) Novi mozhlyvosti terapiyi kohnityvnykh ta depresyvnykh rozladiv pry dystsyrkulyatorniy entsefalopatiyi. [New possibilities for the treatment of cognitive and depressive disorders in dyscirculatory encephalopathy]. Ukrayins'kyy visnyk psykhonevrolohiyi, vol. 26, no 4 (97), pp. 91-100.

11. Emelin KE (2016) Sotsial'noye funktsionirovaniye kak kriteriy effektivnosti terapii bol'nykh s depressivnymi rasstroystvami: obzor literatury [Social functioning as a criterion of effectiveness of therapy in patients with depressive disorders: literature review]. Rossiyskiy psikhiatricheskiy zhurnal, no 3, pp. 61-71. Available at: https://cyberleninka.ru/ article/n/sotsialnoe-funktsionirovanie-kak-kriteriy-effektivnosti-terapii-bolnyh-s-depressivnymi-rasstroystvami-obzor-literatury

12. Ryzhova IA, Samedova EF (2016) Korrektsiya kognitivnykh narusheniy pri rasstroystvakh affektivnogo spektra metodom kognitivnogo treninga [Correction of cognitive impairments in affective spectrum disorders with the method of cognitive training]. Psikhiatriya, psikhoterapiya iklinicheskaya psikhologiya, vol. 7, no 1, pp. 112-121. Available at: https://elibrary.ru/item.asp?id=25462034

13. Nasreddine Z.S., Phillips N.A., Bedirian V. (2005) The Montreal Cognitive Assessment, MoCA: a brief screening tool for mild cognitive impairment. J. Am. Geriatr. Soc., vol. 53 , pp. 695-699.

14. Mioshi E., Dawson K., Mitchell J. (2006) Addenbrooke's Cognitive Examination Revised (ACE-R): a brief cognitive test battery for dementia screening. Int J Geriatr Psychiatry, vol. 21, no 11, pp. 1078-85.

Al'manakh psykholohycheskykh testov [Almanac of psychological tests]. Moskva. 397 p.

6. Tombaugh TN (2004) Trail Making Test A and B: Normative data stratified by age and education. Archives of Clinical Neuropsychology, vol. 19, pp. 203-214.

17. Alfimova MV (2010) Semanticheskaya verbal'naya beglost': normativnyye dannyye i osobennosti vypolneniya zadaniya bol'nymi shizofreniyey. [Semantic verbal fluency: normative data and features of task performance in patients with schizophrenia]. Sotsial'naya i klinicheskaya psikhiatriya, vol. 3, pp. 20-25.

18. Nafees B, van Hanswijck de Jonge P (2012) Reliability and validity of the Personal and Social Performance scale in patients with schizophrenia. Schizophr Res., vol. 140, no $1-3$, pp. $71-76$.

19. Sidorenko YeV (2008) Metody matematicheskoy obrabotki v psikhologi [Methods of mathematical processing in psychology]. SPb.: 000 «Rech'», $350 \mathrm{p}$. 